\title{
Design and Build a Soil Nutrient Measurement Tool for Citrus Plants Using NPK Soil Sensors Based on the Internet of Things
}

\author{
Haristian Pratama ${ }^{1}$, Amsar Yunan $^{2 *}$, Rudi Arif Candra ${ }^{3}$ \\ ${ }_{1,2,3}$ Politeknik Aceh Selatan, Indonesia, \\ haristianpratama981@gmail.com, ${ }^{2 *}$ amsar.yunan@gmail.com, ${ }^{3}$ rudiarifcandra@gmail.com
}

open

access

*Corresponding Author

Article History:

Submitted: 26 Nov 2021

Accepted: 27 Nov 2021

Published: 28 Nov 2021

Keywords:

Nodemcu,

NPK Sensors,

Land

Brilliance: Research of

Artificial Intelligence is licensed

under a Creative Commons

Attribution-NonCommercial 4.0

International (CC BY-NC 4.0).

\begin{abstract}
A suitable planting medium is a medium of good quality soil that can support plant growth quickly. Fertile soil is the primary need for plants. The quality of the planting medium dramatically affects plant growth. The types of soil needed for plant growth vary, namely sandy soil, red soil, alluvial soil, and humus soil. Using an NPK sensor that functions to detect nutrients in the soil and can work if the tip of the sensor is plugged into the soil they want to detect, the results detected by the sensor will be sent in the form of analog signal data to nodemcu, which will be processed and displayed on the screen. Thingspeak. This tool is controlled by nodemcu with an NPK sensor to detect nutrients in the soil with output to thingspeak. The function of the NPK sensor tool will measure the nutrients in the soil for citrus seedlings, and the results read by the Npk sensor will be sent to the Thingspeak web, making it easier for farmers to seed citrus seeds. The data read by the sensor will be sent to thingspeak, making it easier to monitor nutrients in the soil. From the results of the tests carried out, it is found that the nutrient content in wet soil is higher than in dry soil; from the tests carried out, the NPK sensor accuracy rate is $90 \%$.
\end{abstract}

\section{INTRODUCTION}

Different planting media, namely sand, red soil, alluvial soil, humus soil, and sand, are used to overcome the excellent quality of planting media. Among them is using NPK fertilizer, ab mix fertilizer, and other nutrients (Afandi et al., 2018). The accuracy of the Naive Bayes method in classifying soil nutrient content is $100 \%$ obtained from 26 training data and 13 test data. The computational time of the system was obtained by 0.0814 seconds with 26 tests (Anwar et al., 2018). The tool they want to design is a tool that can detect nutrients for growing oranges to overcome the soil conditions suitable for citrus plant nutrients, so we need a tool that can work automatically and can also be monitored remotely in detecting nutrients in plants. Soil that is suitable for growing plants in the form of oranges, with this tool, farmers who want to grow oranges will find it easier to measure the NPK (Nitrogen, Phosphate, and Khalium) nutrients in the soil, and it is easy to add fertilization according to nutrients that can fertilize the citrus plant.

NPK sensor functions to detect nutrients in the soil and can work if the tip of the sensor is plugged into the soil that they want to detect, the results detected by the sensor will be sent in the form of analog signal data to nodemcu, which will be processed and displayed on Thingspeak using the API key that has been registered in the nodemcu program as an address to be displayed on the Thingspek account channel using an internet network that can be monitored from close or remote distances. The first factor nitrogen $(\mathrm{N})$ consists of a ratio of $\mathrm{N} 1=10 \% ; \mathrm{N} 2=15 \% ; \mathrm{N} 3=20 \%$, while for the second factor the ratio of potassium nutrients (K2O) consists of the ratio of $\mathrm{K} 1=5 \%$; K2=7.5\%; K3=10\%; K4 $=12.5 \%$ (Dinarti, N., Fajriani, S., 2019). The nutrient requirements needed by plants for growth and production are determined by the ability of the soil to provide nutrients for plants and cannot always be met (Pinatih et al., 2016). The application of liquid biological fertilizer with a dose of $5 \mathrm{ml} /$ liter of water gave better growth than doses of 0 , 10, and $15 \mathrm{ml} / \mathrm{liter}$ of water, while the application of NPK fertilizer with a dose of $2.25 \mathrm{~g} / \mathrm{seed}$ gave better growth than the dose of $0 ; 4.5$; and $6.75 \mathrm{~g} / \mathrm{seedling}$ (Sinulingga et al., 2015). 


\section{LITERATURE}

\section{A. NodeMCU}

NodeMCU is a hardware module that is open source which means that it can be modified by anyone who wants to develop the nodemcu. 2020) so that every circuit that uses nodemcu is easier to control based on the internet of things because it can be connected directly to wifi (Amsar Yunan, Khairuman, 2020).

\section{B. NPK Soil Sensor}

The soil nitrogen phosphorus and potassium sensor or NPK soil Sensor is a sensor suitable for detecting the nitrogen, phosphorus, and potassium content in the soil, as well as assessing soil fertility by detecting the nitrogen, phosphorus, and potassium content in the soil, thereby facilitating a systematic assessment of soil fertility. The stainless-steel probe of the soil npk sensor can be buried in the soil for a long time and is resistant to long-term electrolysis, salt, and alkali corrosion. The shell is a vacuum pot and is entirely waterproof. It can be applied to detect alkaline soil, acid soil, substrate soil, seedbed soil \& coconut bran soil.

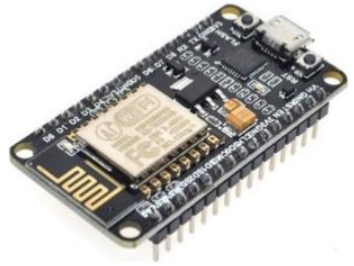

Figure 1. Nodemcu

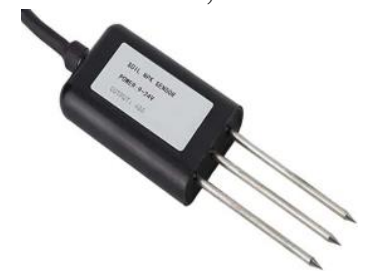

Figure 2. NPK Soil Sensor

\section{Jumper Cable}

Jumper cables are cables used to connect one circuit to another (A. Yunan et al., 2021); with straightforward use, this jumper cable is very much needed when assembling the tool before it is fixed (Adzim, 2018).

\section{E. MAX485 TTL to RS-485}

MAX485 TTL to RS-485 is a serial communication that can transfer differential data from one device to another, and the use of MAX485 TTL to RS-485 is often used to convert data signals from sensor detection to binary numbers that can be displayed directly in inter-applications. The user's face can be run with a positive and negative 5-volt current and can block the current if the current required by the sensor is greater than the current in nodemcu (Kurnia \& H, 2018).

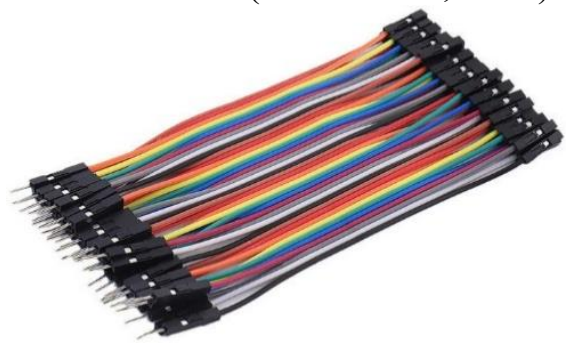

Figure 3. Kabel Jump

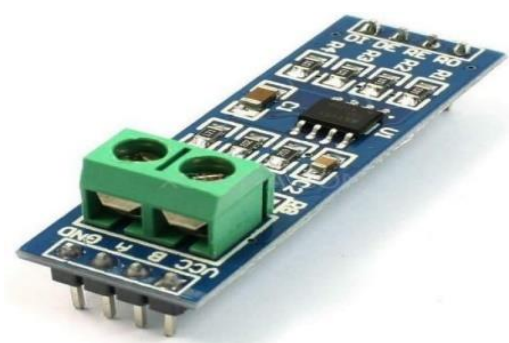

Figure 4. MAX485 TTL to RS-485

\section{F. Thingspeak}

ThingSpeak is a user interface display in the form of an open-source website that can be used to display data from input in the form of sensors or so on (Amsar Yunan, 2020); by using the internet network, Thingspeak can display data following the wishes that have been made with uses HTTP communication as data transmission and is very useful for IoT projects (Sorongan et al., 2018). 


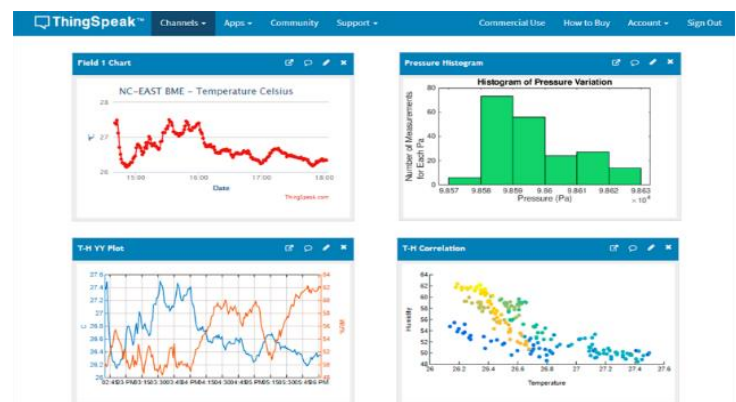

Figure 5. Thingspeak

\section{RESEARCH METHODOLOGY}

\section{A. Tool Specification}

In designing this tool will be discussed the needs that must be met so that this tool can work according to what was planned, namely:

1. Nodemcu can be turned on with a supply voltage of 3.3 Volts, using either a battery or an adapter.

2. Using a 3-channel relay as an automatic switch to control three devices: doors, lights, and fans.

3. Thinkspeak as monitoring media based on internet of things

\section{B. Hardware}

The hardware used in this research method is as follows:

Table 1. Hardware and Specifications

\begin{tabular}{llll}
\hline No & Hardware & Specification & Function \\
\hline 1 & Nodemcu & Amica Versi 3 & Control Board \\
\hline 2 & NPK Soil Sensor & $5-9$ Volt & Nutrient Detection Sensor \\
\hline 3 & Modbus MAX485 & 5 volt & $\begin{array}{l}\text { Data Transfer Module From } \\
\text { Sensor to Nodemcu }\end{array}$ \\
\hline & TTL to RS-485 & & Circuit Connector \\
\hline 4 & Kabel Jumper & Male to Female & Current for circuit \\
\hline 5 & Adaptor & 12 Volt & Current divider \\
\hline 6 & Breadboard & Mini &
\end{tabular}

\section{Software}

The specifications of the software used in this study are:

Table 2. Software and Versions

\begin{tabular}{lll}
\hline No & Software & $\begin{array}{l}\text { Specifications } \\
\text { (Version) }\end{array}$ \\
\hline 1 & Thingspeak & Website \\
\hline 1 & Arduino IDE & 1.8 .2 \\
\hline 2 & Fritzing & $0.9 .2 \mathrm{~b}$ \\
\hline 3 & Windows & 10 \\
\hline 4 & Microsoft Word & 2010 \\
\hline
\end{tabular}




\section{Schematic Design / Block diagram}

This block diagram was created to simplify designing a soil nutrient measuring device for citrus plants using npk soil sensors based on the internet of things. This tool system circuit consists of 3 circuits: the input section, the control section, and the output section.

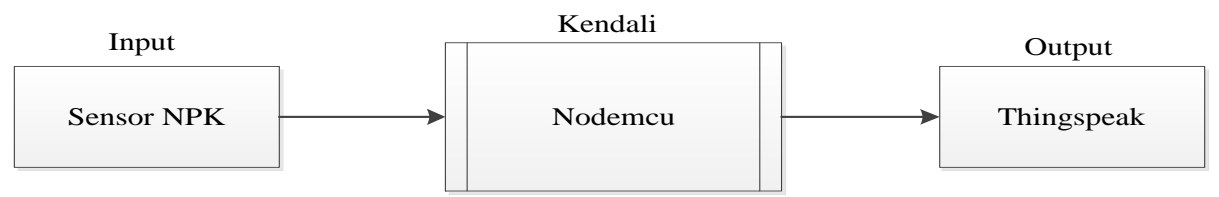

1. Input Section

Figure 6. Block Diagram

The input section consists of an NPK sensor that detects nutrients in the soil they want to plant citrus plants.

2. Control Section

The control section consists of Nodemcu, which controls the entire circuit to work optimally.

3. Output Section

The output section consists of the Thingspeak Web, which displays detection data from sensors sent by nodemcu via API key as the address registered in the program and the Thingspeak account channel.

\section{E. Tool Design}

The design of soil nutrient measuring devices for citrus plants using npk soil sensors based on the internet of things using the Fritzing schematic circuit software:

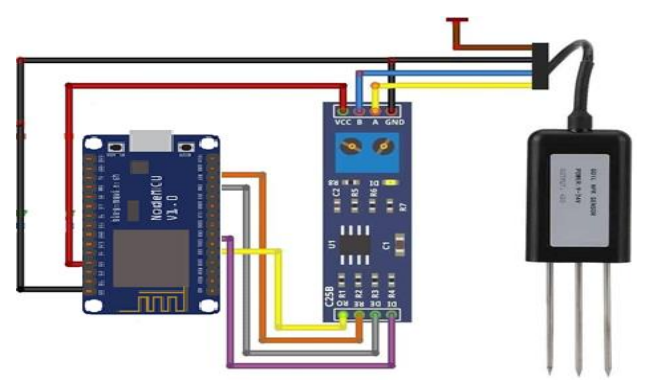

Figure 7. Tool Design

The design of soil nutrient measuring devices for citrus plants using npk soil sensors based on the internet of things using the Fritzing schematic circuit software:

The pins used in this series of tools are pins that can function as current-giving pins and analog signaling pins from the sensor to Modbus and then will be converted by serial communication in Modbus into analog data signals that can be processed by nodemcu. 


\section{F. Tool Sketch}
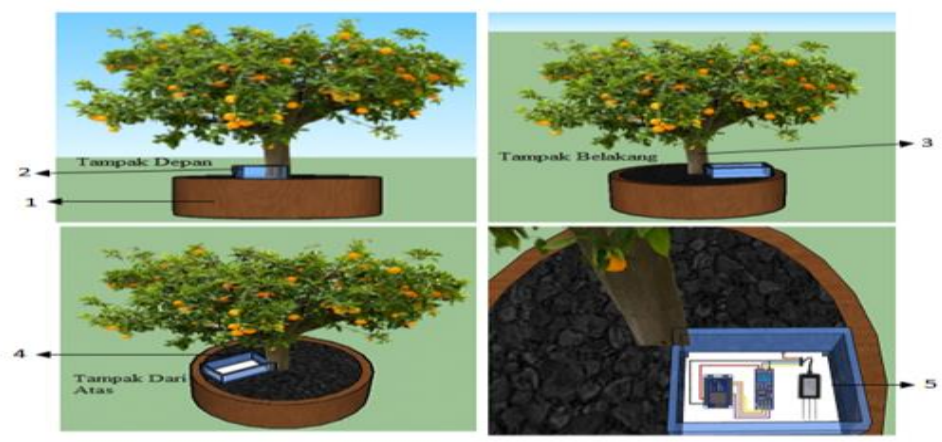

Figure 8. Sketch Tool

1. Toolbox.

2. Orange tree.

3. Soil for citrus trees to be detected for nutrients.

4. Tools that are included in the box

\section{G. Tool Working Principle}

The working principle of a nutrient measuring device in soil for citrus plants using npk soil sensors based on the internet of things is that if the sensor detects nutrients in the soil, the sensor will send data in the form of an analog signal to nodemcu to be processed and will be displayed on thingspeak using the API key. Which has been registered in the nodemcu program and thingspeak account according to the content detected by sensors using the internet network, the nutrients in the soil for citrus plants must have $2.5-3 \%$ for leaf growth to be fertile, if it does not reach that threshold then can be added with regular fertilization so that the nutrients in the soil reach $3 \%$.

\section{H. Flowchart}

A flowchart is a chart or picture that shows the process flow and relationships. Flowcharts are needed to explain the flow of programs made in graphic form so that others can understand the flow that has been made. The following is a flowchart of a Soil Nutrient Measuring Tool for Citrus Plants Using an Internet of Things-Based NPK Soil Sensor.

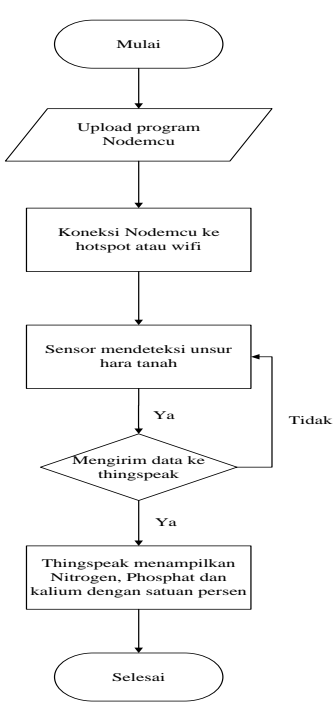

Figure 9. Flowchart Alur Program Nodemcu 
The flowchart above explains the flow of how the program on Nodemcu has five processes, namely:

1. Initialize the cables and ports on the nodemcu connected to the sensor and upload the program used to the nodemcu board.

2. Nodemcu and Thingspeak must be connected to the internet to be monitored remotely.

3. The NPK sensor will detect soil nutrients.

4. The data obtained by the sensor will be sent to the nodemcu, which controls the circuit to be sent to thingspeak.

5. Thingspeak will display soil nutrients in percent units, namely nitrogen, phosphate, and potassium

\section{RESEARCH RESULT}

A. Soil Nutrient Measurement Tool for Citrus Plants Using NPK Soil Sensor Based on Internet of Things On the Vcc, Sensor pin Npk soil pin Vcc Nodemcu, pin Gnd Sensor Npk soil pin Gnd Nodemcu, pin R1 Sensor Npk soil pin D1 Nodemcu, pin R2 Sensor Npk soil pin D2 Nodemcu, Pin R3 Sensor Npk soil pin D3 nodemcu, pin R4 pin D4 nodemcu. As Figure 10.

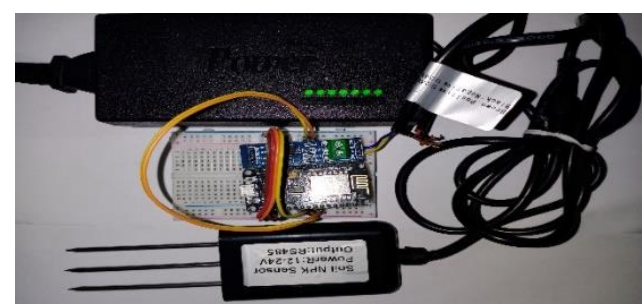

Figure 10. Npk soil sensor

\section{B. Testing Procedure}

The steps taken in the test are:

1. Wet the area of the soil to be tested by providing sufficient water

2. Wait for 1 minute so that the water content is evenly distributed

3. Place the sensor on the ground $\pm 10 \mathrm{~cm}$ from the ground surface to be tested

4. Wait up to 2 minutes for the sensor reading to be sent to thingspeak

5. The test results can be seen using the application included in this test.

After designing and realizing the design of soil nutrient measuring devices for citrus plants using NPK Soil Sensors Based on the Internet of Things, then testing the tools, both in the form of each series and as a whole. After the system is complete, it is necessary to test the system. The NPK sensor will measure nutrients in good soil for citrus plants; if the value of N (Nitrogen), P (Phosphorus), K (Potassium) is above 100 , then the soil is for citrus plant seeds. Here the author conducted the research five times in the Samdua area of South Aceh.

Table 3. testing on citrus plants

\begin{tabular}{|l|l|l|l|l|}
\hline \multirow{2}{*}{ No } & \multirow{3}{*}{ Test } & Nutrient Value in Soil \\
\cline { 3 - 5 } & N & P & K \\
\hline 1 & First & 57 & 131 & 120 \\
\hline 2 & Second & 80 & 128 & 71 \\
\hline 3 & Third & 128 & 150 & 180 \\
\hline 4 & Fourth & 50 & 150 & 125 \\
\hline 5 & Fifth & 50 & 225 & 30 \\
\hline
\end{tabular}


The research results above show that the nutrient content in wet soil is higher than in dry soil; from the tests, the NPK sensor accuracy rate is $90 \%$.

\section{Tool Test Results}

Based on testing of soil nutrient measuring devices for citrus plants in Samadua, South Aceh. The NPK sensor will measure the nutrients in the soil for citrus seedlings, and the results read by the Npk sensor will be sent to the Thingspeak web, making it easier for farmers to seed citrus seeds.
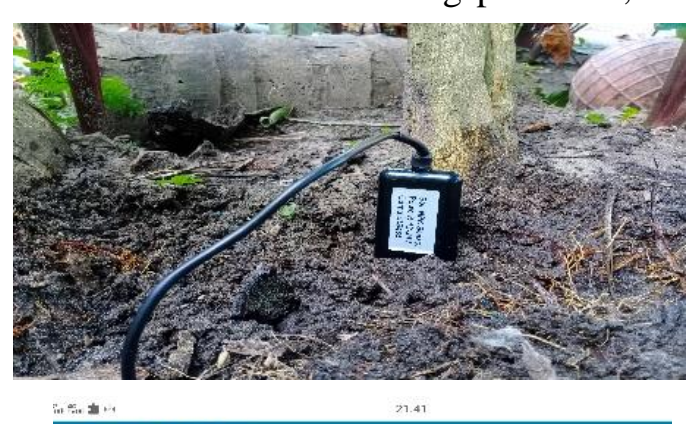

ThingSpeak

Field 2 chart

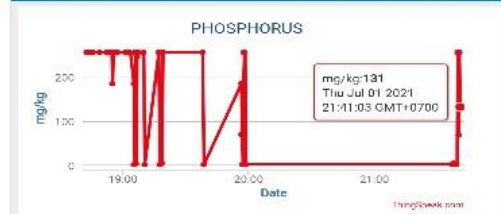

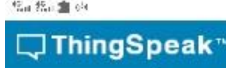

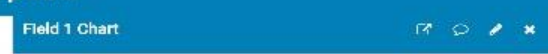

NITROGEN
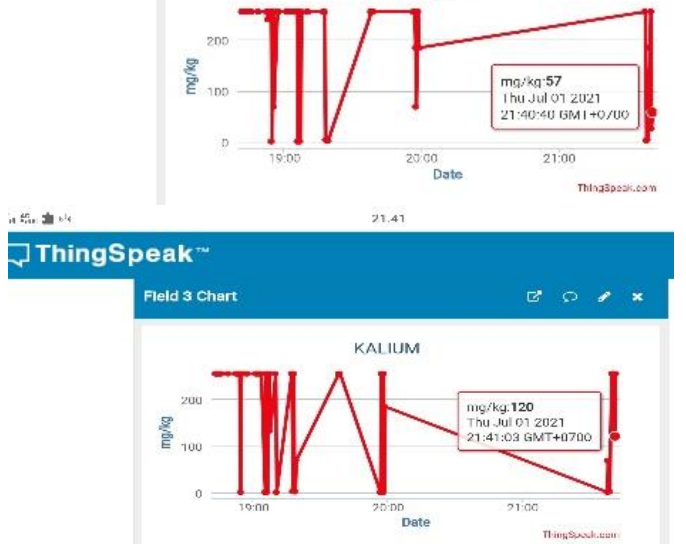

Figure 11. Tool Test Results

\section{CONCLUSION}

The conclusion of this research can be described as follows:

1. The NPK sensor will measure the nutrients in the soil for citrus seedlings, and the results read by the NPK sensor will be sent to the Thingspeak web, making it easier for farmers to seed citrus seeds.

2. The data read by the sensor will be sent to thingspeak, making it easier to monitor nutrients in the soil.

3. The nutrient content in wet soil is higher than in dry soil.

\section{REFERENCE}

Adzim, M. S. (2018). Perancangan Sistem Kendali Otomatis Smart Home Berbasis Android Menggunakan Teknologi WIFI (ESP8266) dan Arduino UNO. Digital Library STMIK GICI.

Afandi, H., Eris, M., \& Ulum, R. (2018). Pembuatan prototipe alat ukur kesuburan tanah berbasis arduino uno. Seminar Nasional Edusainstek FMIPA UNIMUS 2018, 160-165.

Amsar Yunan, Khairuman, M. (2020). PERANCANGAN ALAT PENDETEKSI CO 2 MENGGUNAKAN SENSOR MQ-2 BERBASIS INTERNET OF THING Amsar, Khairuman, Marlina. Methomika, 4(1), 73-79.

Anwar, K., Syauqy, D., \& Fitriyah, H. (2018). Sistem Pendeteksi Kandungan Nutrisi dalam Tanah Berdasarkan Warna dan Kelembapan dengan Menggunakan Metode Naive Bayes. Jurnal Pengembangan Teknologi Informasi Dan Ilmu Komputer, 2(9), 2491-2498. http://j-ptiik.ub.ac.id 
Challa, R., Yamparala, R., Kanumalli, S. S., \& Kumar, K. S. (2020). Advanced Patient's Medication Monitoring System with Ardunio UNO and nodemcu. Proceedings of the 4th International Conference on Electronics, Communication and Aerospace Technology, ICECA 2020, 942-945. https://doi.org/10.1109/ICECA49313.2020.9297420

Dinarti, N., Fajriani, S., Y. S. (2019). Pengaruh Kombinasi Rasio N Dan K Terhadap Pertumbuhan Tanaman Jeruk Siam (Citrus nobilis) pada Fase Vegetatif The Effect Of Ratio N And K Nutrient Combination For Plant Growth Siam Orange (Citrus nobilis) in Vegetative Phase. Jurnal Produksi Tanaman, 7(1), 74-80.

Kurnia, D., \& H, F. S. (2018). Perancangan Kit Praktikum Protokol Modbus Rtu Berbiaya Rendah Berbasis Arduino Mega. Elektra, 3(2), 11-18.

Pinatih, I., Kusmiyarti, T., \& Susila, K. (2016). Evaluasi Status Kesuburan Tanah Pada Lahan Pertanian Di Kecamatan Denpasar Selatan. E-Jurnal Agroekoteknologi Tropika (Journal of Tropical Agroecotechnology), 4(4), 282-292.

Sinulingga, E., Ginting, J., \& Sabrina, T. (2015). Pengaruh Pemberian Pupuk Hayati Cair Dan Pupuk Npk Terhadap Pertumbuhan Bibit Kelapa Sawit Di Pre Nursery. Jurnal Agroekoteknologi Universitas Sumatera Utara, 3(3), 1219-1225. https://doi.org/10.32734/jaet.v3i3.11012

Sorongan, E., Hidayati, Q., \& Priyono, K. (2018). ThingSpeak sebagai Sistem Monitoring Tangki SPBU Berbasis Internet of Things. JTERA (Jurnal Teknologi Rekayasa), 3(2), 219-224. https://doi.org/10.31544/jtera.v3.i2.2018.219-224

Yunan, A., Satria, E., Ilham, D. N., Anugreni, F., Khairuman, K., \& Sandra, S. (2021). Signal jammer reduces wireless fidelity network and global system in the local environment. IOP Conference Series: Earth and Environmental Science, 644(1). https://doi.org/10.1088/1755-1315/644/1/012022

Yunan, Amsar. (2020). Optimization Of Server Computer Security Using The Port Knocking Method On Ubuntu Server 12.04 LTS. Jurnal Inotera, 5(1), 26-34. https://doi.org/10.31572/inotera.vol5.iss1.2020.id96 